\title{
MELATIHKAN KETERAMPILAN KOMUNIKASI MELALUI MODEL PEMBELAJARAN KOOPERATIF TIPE THINK PAIR SHARE (TPS) PADA MATERI ASAM BASA
}

\section{TRAINNING THE COMMUNICATION SKILLS THROUGH THE APPLICATION OF COOPERATIVE LEARNING MODEL OF THINK PAIR SHARE (TPS) TYPE ON ACID BASE}

\author{
Dea Sarah Tia dan *Muchlis \\ Jurusan Kimia FMIPA Universitas Negeri Surabaya \\ e-mail: muchlis@unesa.ac.id
}

\begin{abstract}
Abstrak
Tujuan penelitian ini dibuat untuk mendeskripsikan keterlaksanaan model pembelajaran kooperatif tipe Think Pair Share (TPS), aktivitas peserta didik, keterampilan komunikasi yang berupa kualitas dan kuantitas, ketuntasan hasil belajar dan respon dari peserta didik setelah diterapkannya model pembelajaran kooperatif tipe TPS di SMAN 17 Surabaya. Desain penelitian yang digunakan adalah "One Shoot Case Study" dengan subyek penelitian yaitu peserta didik kelas XI IPA 1. Data hasil penelitian menunjukkan bahwa (1) Keterlaksanaan sintaks model pembelajaran kooperatif tipe (TPS) tiap pertemuan memperoleh kategori sangat baik, dengan skor nilai rata-rata pertemuan 1, 2 dan 3 berturut-turut sebesar 3,6; 3,75; dan 4. (2) Aktivitas peserta didik yang relevan rata-rata pertemuan 1, 2 dan 3 berturut-turut sebesar 98,12\%; 99,17\%; dan 99,3\%. (3) Keterampilan komunikasi yang berupa kuantitas bertanya pada pertemuan 1, 2 dan 3 berturut-turut persentasenya sebesar 28,1\%; 50\%; dan 56,2\% dengan kriteria cukup baik. Kuantitas berpendapat persentase 43,7\%; 62,5\%; dan 65,6\% dengan kriteria cukup baik. Kualitas berpendapat dengan kriteria baik sebanyak 37,5\%; 56,25\%; dan 59,37\%. Keterampilan komunikasi yang berupa kualitas bertanya, mendapat kriteria baik sebanyak $0 \%, 6,25 \%$, dan 6,25\%. (4) Peserta didik mengalami ketuntasan hasil belajar dengan mendapatkan persen ketuntasan 86,18\%. (5) Hasil angket respon peserta didik terhadap penerapan model pembelajaran kooperatif tipe Think Pair Share (TPS) memperoleh hasil respon yang positif dengan persentase seluruh item $\geq 61 \%$.
\end{abstract}

Kata Kunci: Kooperatif Tipe Think Pair Share (TPS), Keterampilan Komunikasi, Asam Basa

\begin{abstract}
The purpose of this study was made to describe the implementation of the Think Pair Share (TPS) type of cooperative learning model, students' activities, communication skills in the form of quality and quantity, completeness of learning outcomes and responses of students after the application of the type of cooperative learning model at SMAN 17 Surabaya. The research design used was "One Shoot Case Study" with research subjects namely students of class XI IPA 1. Research data shows that (1) The syntax of the type of cooperative learning model (TPS) at each meeting obtained a very good category, with scores the average meeting 1, 2 and 3 in a row of 3.6; 3.75; and 4. (2) Activities of relevant students averaging meetings 1, 2 and 3 respectively at 98.12\%; 99.17\%; and 99.3\%. (3) Communication skills in the form of quantity asking questions at meetings 1, 2 and 3 in a row the percentage is 28.1\%; 50\%; and $56.2 \%$ with quite good criteria. Quantity holds the percentage of 43.7\%; 62.5\%; and 65.6\% with quite good criteria. Quality of opinion with good criteria as much as 37.5\%; 56.25\%; and 59.37\%. Communication skills in the form of quality questions, get good criteria as much as $0 \%, 6.25 \%$, and $6.25 \%$. (4) Students experience mastery of learning outcomes by getting $86.18 \%$. (5) The results of students' questionnaire responses to the application of the Think Pair Share (TPS) cooperative learning model obtained positive response results with the percentage of all items $\geq 61 \%$.
\end{abstract}

Key Words: Cooperative Learning, Think Pair Share Type (TPS), Communication Skills, Acid and Bases

\section{PENDAHULUAN}

Pendidikan adalah sebagai sebuah usaha bagi manusia dalam rangka mengembangkan potensi yang mereka punyai melalui sebuah pembelajaran untuk mencapai tujuan pendidikan nasional. Cara untuk mencapainya salah satunya yaitu peningkatan sebuah mutu pendidikan pada tiap pendidikan yang ada melalui cara 
pengembangan kurikulum. Kurikulum 2013 dirancang oleh pemerintah untuk mewujudkan tujuan pendidikan yaitu untuk membantu mengembangkan sikap spiritual dan sosial, kerja sama dengan kemampuan intelektual serta kemampuan berkomunikasi [1].

Kehidupan pada abad ke-21 sekarang banyak sekali yang menuntut manusia untuk memiliki berbagai macam keterampilan yang harus dikuasai, sehingga diharapkan ketika terjun dalam kehidupan bermasyarakat dapat mempersiapkan untuk bisa menguasai berbagai keterampilan agar menjadi pribadi yang sukses dalam kehidupan bermasyarakat. Salah satu keterampilan yang harus dimiliki dan dapat dilatihkan didalam kelas adalah keterampilan komunikasi [2].

Santrock menuliskan pada bukunya bahwa komunikasi tersebut terdiri dari keterampilan berbicara, keterampilan mendengar, dan non verbal. Keterampilan berbicara ada dua yaitu keterampilan bertanya dan berpendapat [3]. Guru memegang peran penting dalam membangun pembelajaran di dalam kelas termasuk penataan kelompok maupun tugasnya [4]. Serta membantu peserta didik untuk berinteraksi dan bekerja sama dengan temannya dan menerima tanggung jawab atas tugas yang mereka dapatkan. Mengutarakan pendapat yang harus mereka buat, sehingga meningkatkan kemampuan untuk berkomunikasi [5].

Salah satu materi dalam pembelajaran kimia yaitu asam basa. Materi ini dapat digunakan dalam melatihkan komunikasi karena asam basa kerap dijumpai di dalam kehidupan sehari-hari. Sehingga memungkinkan timbul pertanyaan ataupun tanggapan dan memicu adanya komunikasi yang dilakukan [6]

Didukung oleh hasil pra-peneltian yang dilakukan di SMAN 17 Surabaya pada hari Kamis, 14 November 2019, sebanyak 66,7\% peserta didik kelas XI IPA 1 menyatakan bahwa pembelajaran berlangsung selama ini kebanalan menggunakan metode ceramah berpusat pada guru, dan pembelajaran cenderung tidak aktif yang didukung dengan pengamatan peneliti pada pembelajaran di kelas. Pengamatan ini diamati secara kuantitatif dengan melihat dari banyaknya peserta didik yang bertanya maupun berpendapat dalam proses pembelajaran. Hasil prapenelitian didapatkan persentase peserta didik yang bertanya dan berpendapat sebanyak $3,7 \%$ dan 3,7\%. Hasil tersebut menunjukkan bahwa keaktifan dari peserta didik tergolong masih rendah dan guru lebih mendominasi saat proses pembelajaran berlangsung. Hasil angket yang diisi oleh peserta didik juga mendukung bahwa sebanyak 92,59\% peserta didik lebih senang ketika belajar berkelompok karena peserta didik dapat memperoleh ilmu pengetahuan, wawasan maupun pengalaman [7].

Model pembelajaran yang diinginkan adalah yang sesuai dan memudahkan peserta didik untuk dapat memahami materi yang dipelajari. Serta mampu melatihkan keterampilan komunikasi [8]. Pebelajaran kooperatif bertujuan untuk mengembangkan keterampilan sosial. Model pembelajaran ini bisa digunakan untuk melatihkan keterampilan komunikasi peserta didik [9].

Model pembelajaran kooperatif salah satu tipenya adalah Think Pair Share (TPS) merupakan model pembelajaran untuk meningkatkan perolehan dalam akademik dengan pendekatan struktural. Tujuan dari pembelajaran tipe TPS adalah peserta didik bekerja sama untuk saling tolong-menolong dalam sebuah kelompok dan salah satu cirinya yaitu dengan memberikan penghargaan berkelompok, daripada penghargaan individu. Pada pembelajaran TPS keterampilan komunikasi dapat dilatihkan pada tahap Pair dan Share [10]. Hasil penelitian menyatakan bahwa strategi pembelajaran TPS dapat melatihkan keterampilan berbicara peserta didik. Peserta didik dapat menjadi aktif berbicara [11]. Terdapat beberapa keunggulan model pembelajaran kooperatif tipe TPS salah satunya adalah adanya waktu untuk mendiskusikan ide antar peserta didik sehingga komunikasi peserta didik bisa berjalan lebih aktif [12].

Bekerja sama itu sangat penting dalam lingkungan belajar. Karenanya, dalam metode ini, mereka memiliki kesempatan untuk bekerjasama dengan teman-teman yang berbeda dan belajar 
secara kooperatif [7]. Selain itu, peserta didik menekankan bahwa untuk bekompetisi dengan tim lain, mereka memotivasi teman mereka yang lemah dan memperbaiki kekurangan. Selain itu, peserta didik juga harus mengetahui tujuan bersama dalam proses ini maka akan mempengaruhi keberhasilan kelompok. Maka dari itu peserta didik harus bisa bekerja sama untuk menuntaskan permasalahan yang terdapat dalam kelompoknya [13].

Berdasarkan dari latar belakang yang dituliskan di atas, maka perlu dilakukan penelitian "Melatihkan Keterampilan Komunikasi Peserta Didik Melalui Model Pembelajaran Kooperatif Tipe TPS pada Materi Asam Basa di SMAN 17 Surabaya". Berdasarkan penelitian tersebut, untuk meyakinkan bahwa keterampilan komunikasi peserta didik dapat dilatihkan sebagai hasil penelitian ini, maka perlu diamati keterlaksanaan model pembelajaran yang akan digunakan untuk melatihkan keterampilan komunikasi peserta didik. Selain itu, untuk mengetahui bahwa perilaku peserta didik telah relevan dengan sintaks model pembelajaran yang digunakan dan peserta didik telah berlatih keterampilan komunikasi, maka perlu diamati aktivitas peserta didik saat pembelajaran berlangsung.

\section{METODE}

Jenis penelitian yaitu pre-eksperimental dengan rancangan "One Shoot Case Study Design" dengan satu kelas saja tanpa kelas pembanding yang dapat dijabarkan sebagai berikut:

\section{$\mathrm{X} \rightarrow \mathrm{O}$}

Keterangan:

$\mathrm{X}$ :Treatment yang diberikan (variabel independen) (melatihkan keterampilan komunikasi awal peserta didik sebelum diterapkannya model pembelajaran kooperatif tipe TPS pada materi asam basa).

O :Observasi (Variabel dependen) Hasil penerapan model pembelajaran kooperatif tipe TPS pada materi asam basa di akhir pertemuan.

Subjek dalam penelitian ini adalah peserta didik kelas XI dan pelaksanaannya pada semester genap tahun ajaran 2019/2020 ketika memasuki materi asam basa.

Keterlaksanaan ini digunakan untuk mengetahui kualitas proses pembelajaran yang sesuai dengan semua sintaks model kooperatif berdasarkan RPP yang telah dibuat oleh peneliti. Model pembelajaran ini mengubah pola wacana di dalam kelas. Diskusi perlu dilakukan dan memiliki beberapa langkah supaya memberikan lebih banyak waktu kepada peserta didik dalam melakukan proses berpikir, merespon, dan untuk saling membantu [14]. Elemen kunci pembentukan kemandirian peserta didik yang bertujuan positif sehingga anggota kelompok memahami bahwa mereka dituntut tidak hanya menyelesaikan bagian pekerjaan mereka tetapi juga memastikan bahwa teman satu kelompoknya juga menyelesaikan pekerjaannya [15]. Pengamatan tersebut akan diamati oleh dua orang pengamat. Skor kriteria penilaian keterlaksanaan sintaks model pembelajaran kooperatif tertera.

Tabel 1 Rubrik Penilaian Skor Keterlaksanaan

\begin{tabular}{cc}
\hline Skor & Keterangan \\
\hline 1 & Kurang baik \\
2 & Cukup \\
3 & Baik \\
4 & Sangat baik \\
\hline
\end{tabular}

Pemberian skor pada penilaian keterlaksanaan model dalam pembelajaran kooperatif tipe TPS kemudian dianalisis melalui rumus berikut:

Keterlaksanaan $=\frac{\sum \text { Tiap langkah yang diperoleh }}{\sum \text { Langkah yang diperoleh }} \times 100$

Nilai yang diperoleh kemudian dikonversikan seperti Tabel 2.

Tabel 2 Kriteria Kualitas Keterlaksanaan Model Pembelajaran

\begin{tabular}{cc}
\hline Skor & Keterangan \\
\hline $3,1-4$ & Sangat Baik \\
$2,1-3$ & Baik \\
$1,1-2$ & Cukup \\
$0-1$ & Buruk \\
\hline
\end{tabular}


Kualitas keterlaksanaan model pembelajaran kooperatif tipe TPS dikatakan baik jika nilai kualitas keterlaksanaanyang di dapat $\geq 2,1$ yaitu pada kategori baik atau sangat baik. Karena itu, guru harus bisa meningkatkan kualitas belajar mengajar di kelas [17]

Aktivitas peserta didik dianalisis dengan mengamati peserta didik setiap 3 menit sekali selama 90 menit oleh 6 pengamat dan data dari 6 pengamat tersebut akan dirata-rata. Data tersebut kemudian akan dianalisis dengan menghitung persentase aktivitas peserta didik selama pembelajaran, dengan menggunakan rumus:

$\%$ Aktivitas $=\frac{\sum \text { Frekuensi yang sering muncul }}{\sum \text { Frekuensi aktivitas keseluruhan }} \times 100$

Aktivitas peserta didik dapat dikatakan mendukung keefektifan penerapan model pembelajaran kooperatif tipe TPS untuk melatihkan keterampilan komunikasi apabila persentase aktivitas yang relevan lebih besar dari aktivitas tidak relevan [18].

Data keterampilan komunikasi diperoleh dari pengamatan bertanya dan berpendapat peserta didik secara individu. Data keterampilan komunikasi yang diteliti meliputi keterampilan bertanya dan berpendapat dalam segi kualitas dan kuantitas. Kuantitas komunikasi diukur dengan menggunakan rumus sebagai berikut :

$\%$ Kuantitas $=\frac{\sum \text { Peserta didik yang berkomunikasi }}{\sum \text { Seluruh peserta didik }} \times 100$

Sedangkan kualitas komunikasi diukur menggunakan rumus sebagai berikut:

$$
\% \text { Kualitas }=\frac{\sum \text { Skor yang diperoleh }}{\sum \text { Skor maksimal }} \times 100
$$

Selanjutnya, persentase kualitas dan kuantitas diinterpretasikan dalam tabel 3

Tabel 3 Interpretasi Kuantitas dan Kualitas komunikasi

\begin{tabular}{cc}
\hline Skor Siswa (\%) & Kategori \\
\hline $0-33,33$ & Kurang Baik \\
$33,34-66,67$ & Cukup Baik \\
$66,68-100$ & Baik
\end{tabular}

Ketuntasan hasil belajar yang diperoleh setelah diterapkan suatu model pembelajaran menggunakan rentang penilaian dalam bentuk angka skala 0-100. Ketuntasan klasikal dapat diaggap tercapai jika pada posttest $\geq 75 \%$ peserta didik di kelas mencapai ketuntasan individu.

Respon peserta didik dinilai positif, apabila perolehan persentase sebesar $\geq 61 \%$, maka dianggap seluruh peserta didik setuju dan model pembelajaran kooperatif tipe TPS efektif digunakan dalam kegiatan pembelajaran untuk melatihkan keterampilan komunikasi pada materi asam basa. Kriteria respon dapat dilihat pada:

Tabel 4 Kriteria Respon Peserta Didik

\begin{tabular}{ccc}
\hline No. & Presentase (\%) & Kriteria \\
\hline 1 & $0-20$ & Tidak Puas \\
2 & $21-40$ & Kurang Puas \\
3 & $41-60$ & Cukup puas \\
4 & $61-80$ & Memuaskan \\
5 & $81-100$ & Sangat Memuaskan \\
\hline
\end{tabular}

\section{HASIL DAN PEMBAHASAN}

\section{KETERLAKSANAAN PEMBELAJARAN}

Keterlaksanaan model ini dilaksanakan guru dalam hal ini yaitu peneliti dan pelaksanaannya disesuaikan RPP yang disusun sebelumnya. Hasil ini diperoleh dengan cara menggunakan instrumen lembar pengamatan keterlaksanaan pembelajaran kooperatif tipe TPS serta diamati oleh 2 pengamat yang terdiri dari mahasiswa Jurusan Pendidikan Kimia Unesa. Diagram pengamatan keterlaksanaan model ini terdapat dalam Gambar 1.

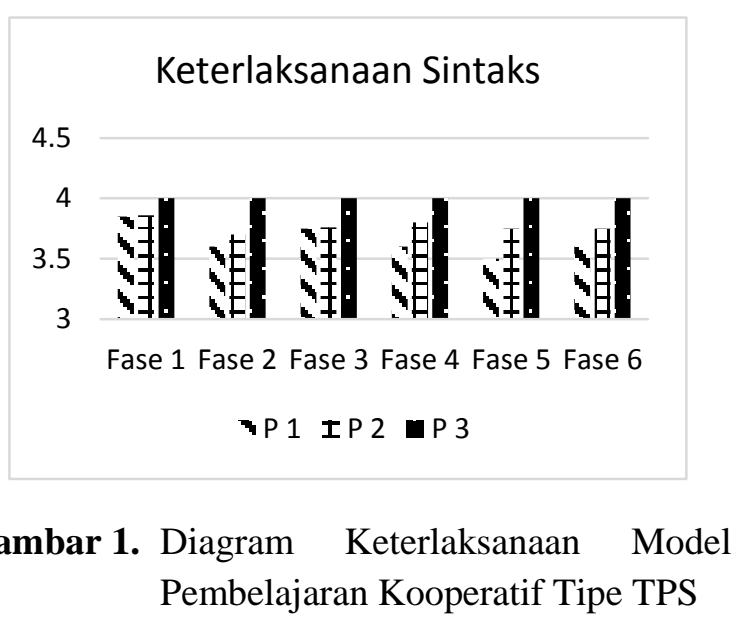

Gambar 1. Diagram Keterlaksanaan Model
Pembelajaran Kooperatif Tipe TPS 
Skor nilai dari rata-rata keterlaksanaan yang didapat selama tiga kali tatap muka adalah sebesar 3,78 predikat yang didapat yaitu sangat baik, artinya keterlaksanaan pembelajaran terlaksana dengan sangat baik. Keterlaksanaan pembelajaran ini dikatakan baik jika nilai kualitas keterlaksanaan memperoleh hasil $\geq 2,1$ yaitu dengan kategori baik atau sangat baik. Sintak model pembelajaran diambil skor yang diperoleh tersebut menunjukkan bahwa guru menerapkan sintaks model pembelajaran kooperatif tipe TPS ini dengan baik.

\section{AKTIVITAS PESERTA DIDIK}

Aktivitas ini diamati dengan tujuan untuk mengetahui kesesuaian seluruh aktivitas selama pembelajaran berlangsung melalui sintaks model pembelajaran koperatif tipe TPS serta dapat bertujuan mengetahui keterampilan komunikasi peserta didik yang meliputi bertanya dan berpendapat.

Hasil aktivitas ini diperoleh melalui instrumen dari lembar pengamatan aktivitas peserta didik dan diamati 5 pengamat, terdiri dari mahasiswa Jurusan Pendidikan Kimia Unesa. Setiap pengamat memiliki tugas untuk mengamati 3 kelompok yang beranggotakan 2 peserta didik dan satu kelas terdiri dari 5 kelompok. Pengamat mengamati aktivitas yang dominan muncul setiap 3 menit sekali selama 90 menit pembelajaran. Hasil rekapitulasi pengamatan aktivitas peserta didik selama tiga kali tatap muka dapat dilihat pada Tabel 5 .

Tabel 5. Rekapitulasi Pengamaan Aktivitas Peserta Didik

\begin{tabular}{lccc}
\hline \multicolumn{1}{c}{\begin{tabular}{c} 
Aktivitas Peserta \\
\multicolumn{1}{c}{ Didik }
\end{tabular}} & \multicolumn{3}{c}{ Persentase (\%) } \\
& P1 & P2 & P3 \\
\hline $\begin{array}{l}\text { Menyimak penjelasan } \\
\text { guru }\end{array}$ & 38 & 24,7 & 24,4 \\
$\begin{array}{l}\text { Mengajukan pendapat } \\
\text { dalam forum klasikal }\end{array}$ & 1,04 & 1,67 & 1,88 \\
$\begin{array}{l}\text { Mengajukan pertanyaan } \\
\text { dalam forum klasikal }\end{array}$ & 1,46 & 2,08 & 2,19 \\
$\begin{array}{l}\text { Menyimak penjelasan } \\
\text { teman }\end{array}$ & 16,8 & 14,1 & 13,8 \\
\hline
\end{tabular}

\begin{tabular}{|c|c|c|c|}
\hline \multirow{2}{*}{$\begin{array}{c}\text { Aktivitas Peserta } \\
\text { Didik }\end{array}$} & \multicolumn{3}{|c|}{ Persentase (\%) } \\
\hline & P1 & P2 & P3 \\
\hline Melakukan percobaan & 0 & 26 & 26,3 \\
\hline $\begin{array}{l}\text { Mengerjakan LKPD } \\
\text { secara mandiri }\end{array}$ & 16,1 & 10 & 10 \\
\hline $\begin{array}{l}\text { Mendiskusikan LKPD } \\
\text { dengan kelompok }\end{array}$ & 13,2 & 10 & 10 \\
\hline $\begin{array}{l}\text { Mengkomunikasikan/ } \\
\text { Presenrtasi }\end{array}$ & 1,67 & 0,63 & 0,73 \\
\hline Menyimpulkan materi & 6,67 & 6,67 & 66,7 \\
\hline Pemberian penghargaan & 3,33 & 3,33 & 3.33 \\
\hline Aktivitas yang relevan & $\begin{array}{c}98,1 \\
2\end{array}$ & $\begin{array}{c}99,1 \\
7\end{array}$ & 99,3 \\
\hline $\begin{array}{l}\text { Aktivitas tidak relevan } \\
\text { (bermain HP, berbicara } \\
\text { sendiri, dll) }\end{array}$ & 1,88 & 0,83 & 0,7 \\
\hline Total & 100 & 100 & 100 \\
\hline $\begin{array}{l}\text { Berdasarkan desk } \\
\text { di atas bahwa peserta did } \\
\text { relevan dalam arti peser } \\
\text { keterampilan komunikasi } \\
\text { dalam sintaks model } \\
\text { digunakan pada materi } \\
\text { pertemuan 1, 2, dan } 3 \\
98,12 \% \text {; 99,17\%; dan } \\
\text { dituliskan menunjukkan } \\
\text { dikatakan mendukung } \\
\text { model karena persentase } \\
\text { besar dibandingkan de } \\
\text { relevan. }\end{array}$ & $\begin{array}{l}\text { ripsi ak } \\
\text { dik mel } \\
\text { ta didi } \\
\text { dan be } \\
\text { pemb } \\
\text { asam } \\
\text { persen } \\
99,3 \% \\
\text { bahwa } \\
\text { keefekt } \\
\text { aktivit } \\
\text { ngan }\end{array}$ & $\begin{array}{l}\text { ivitas } \\
\text { kukan } \\
\text { telah } \\
\text { aktivit } \\
\text { elajara } \\
\text { basa } \\
\text { asenya } \\
\text { Has } \\
\text { aktivit } \\
\text { fan p } \\
\text { s reles } \\
\text { aktivita }\end{array}$ & $\begin{array}{r}\text { ang ada } \\
\text { aktivitas } \\
\text { berlatih } \\
\text { s sesuai } \\
\text { yang } \\
\text { dengan } \\
\text { sebesar } \\
1 \text { yang } \\
\text { s dapat } \\
\text { nerapan } \\
\text { an lebih } \\
; \text { tidak }\end{array}$ \\
\hline
\end{tabular}

\section{KETERAMPILAN KOMUNIKASI}

Keterampilan komunikasi yang dilatihkan adalah keterampilan bertanya dan berpendapat. Berikut akan dijelaskan hasil pengamatan keterampilan komunikasi yang berupa kualitas dan kuantitas bertanya maupun berpendapat.

a. Kuantitas Bertanya dan Berpendapat

Kuantitas bertanya dapat diketahui melalui banyaknya peserta didik yang bertanya, bukan dari banyaknya pertanyaan yang dikemukakan peserta didik. Contoh pertanyaan yang diajukan yaitu "Terbuat dari apakah kertas lakmus itu?" dan "Mengapa indikator PP 
tidak bisa mengidentifikasi larutan yang pHnya kurang dari 8,3?". Contoh pendapat yang diajukan yaitu "Indikator asam basa adalah senyawa khusus yang digunakan untuk mengetahui sifat dan kisaran $\mathrm{pH}$ suatu larutan" dan "Kegunaan asam dalam kehidupan seharihari contohnya sebagai pengawet makanan asam benzoat". Berikut merupakan data kuantitatif keterampilan komunikasi selama tiga pertemuan. Diagram Kuantitas Komunikasi terdapat dalam Gambar

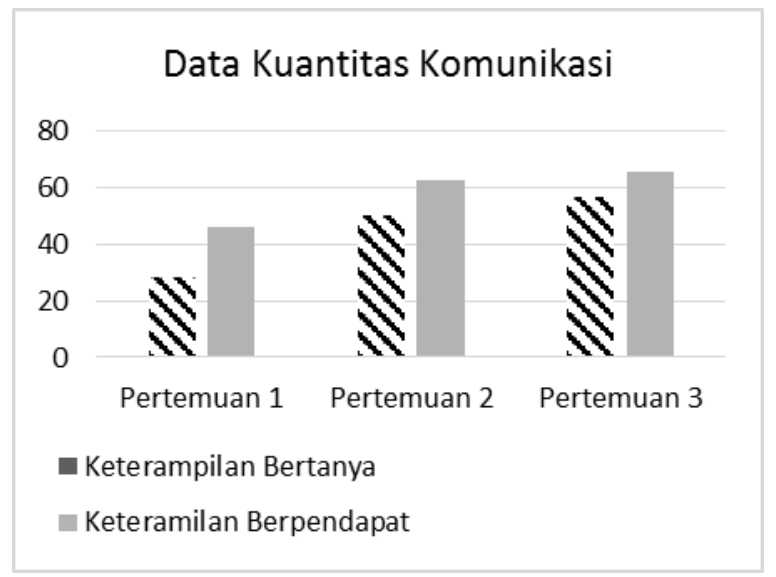

Gambar 2. Diagram Data Kuantitas Bertanya dan Berpendapat

Persentase kuantitas bertanya pada peserta didik pada Gambar 2 mengalami perubahan dari pertemuan satu ke pertemuan dua, maupun dipertemuan tiga, Persentase kuantitas berpendapat juga mengalami peningkatan mulai dari pertemuan satu hingga ke pertemuan tiga. Artinya peserta didik mengalami kemajuan dalam mengemukakan pendapat.

Namun, masih juga terdapat peserta didik yang tidak bertanya serta berpendapat selama tiga kali pertemuan, hal ini dikarenakan komunikasi yang aktif belum menjadi kebiasaan yang dilakukan [19]. Sesuai teori operant conditioning yang tuliskan oleh Skinner. Menurut Skinner dan Santrock pemberian penguatan (positif ataupun negatif) dapat menjadikan terbentuknya perilaku yang diinginkan atau yang tidak diinginkan serta berlangsung lama [17]. Sesuai dengan teori tersebut keterampilan komunikasi perlu dilatihkan dalam waktu yang lama agar mendapatkan hasil yang memuaskan.

Berdasarkan Gambar 2 kuantitas komunikasi peserta didik berada di kategori cukup baik untuk semua pertemuan. Berdasarkan gambar tersebut maka kesimpulannya adalah penerapan model pembelajaran kooperatif tipe (TPS) dapat melatihkan keterampilan berkomunikasi peserta didik untuk bertanya maupun berpendapat.

b. Kualitas Bertanya dan Berpendapat

Kualitas bertanya peserta didik diamati dengan cara menganalisis setiap pertanyaan yang diutarakan oleh peserta didik, pertanyaan tersebut tergolong dalam tingkatan Taksonomi Bloom. Terdapat 6 tingkatan Taksonomi Bloom, tingkatan itu adalah C1 hingga C6 [20]. Namun, pada penelitian ini kualitas bertanya peserta didik yang tercapai hanya $\mathrm{C} 1$ sampai $\mathrm{C} 3$.

Pada pertemuan satu, kategori bertanya mendapat kategori cukup baik terdapat sebanyak 11 anak, mendapat kategori kurang baik sebanyak 21 anak. Pada pertemuan dua, kategori bertanya baik didapatkan oleh 2 anak, kategori cukup baik 14 peserta didik, dan yang mendapatkan kategori kurang baik sebanyak 16 anak. Pada pertemuan tiga, kategori baik didapatkan oleh 2 anak, kategori cukup baik sebanyak 17 anak, dan kategori kurang baik sebanyak 13 anak. Berikut merupakan data kualitas bertanya peserta didik.

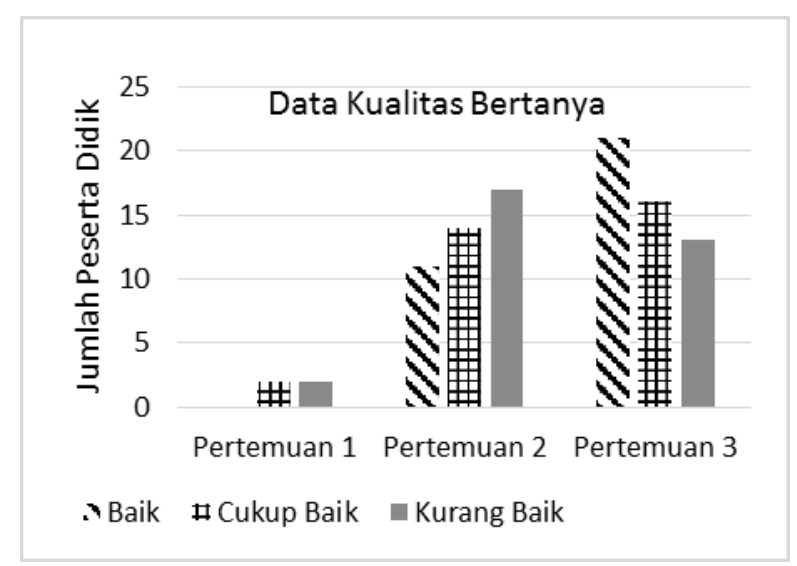

Gambar 3. Diagram Data Kualitas Komunikasi Bertanya Peserta Didik

Kualitas bertanya peserta didik pada pertemuan satu hingga tiga mengalami kenaikan serta pencapaian kualitas bertanya peserta didik hanya $\mathrm{C} 1$ sampai $\mathrm{C} 3$. Hal ini menunjukkan bahwa keterampilan komunikasi berupa kualitas bertanya dalam kategori cukup baik, meskipun kualitas bertanya yang mampu dicapai oleh 
peserta didik terbatas pada $\mathrm{C} 3$, karena peserta didik belum terbiasa bertanya dengan memperhatikan kualitasnya.

c. Kualitas Berpendapat

Kualitas berpendapat peserta didik dinilai berdasarkan kelogisan dan keanalitisan setiap pendapat yang diberikan. Dikatakan analitis, apabila menyampaikan informasi dengan kata yang jelas, sehingga informasi yang disampaikan dapat dimengerti oleh pendengarnya. Pendapat logis, apabila menyampaikan informasi yang dilandasi dengan fakta atau kenyataan yang bisa mendukung pendapat yang disampaikan.

Pada pertemuan satu, 12 anak memperoleh kategori berpendapat baik, 2 anak mendapatkan kategori cukup baik, dan 18 anak mendapat kategori kurang baik. Pada pertemuan dua, peserta didik berpendapat dengan kategori baik sebanyak 18 , cukup baik sebanyak 2 , dan kurang baik sebanyak 12 anak. Pada pertemuan tiga, peserta didik yang mendapatkan kategori baik sebanyak 19 anak, cukup baik sebanyak 2 anak, dan kategori kurang baik sebanyak 11 anak.

Kualitas berpendapat yang dikemukakan oleh peserta didik pada pertemuan satu hingga pertemuan tiga bermacam-macam. Menurut Effendy keterampilan komunikasi peserta didik dalam berpendapat bisa diukur dari seberapa efektif isi pesan yang disampaikan [6].

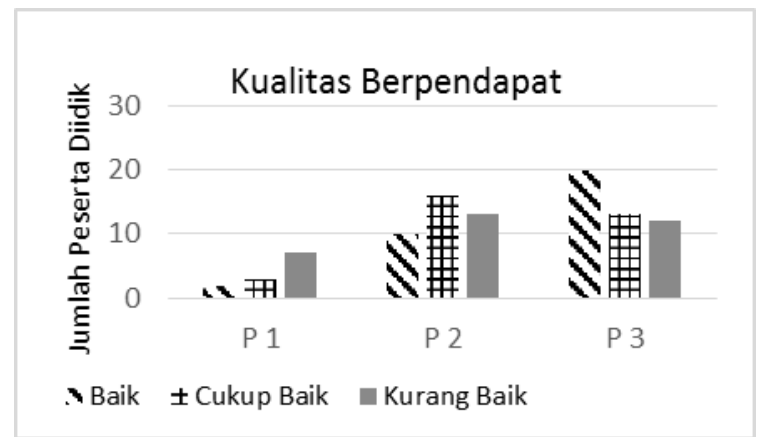

Gambar 4. Diagram Data Kualitas Komunikasi Berpendapat Peserta Didik

Peningkatan kualitas berpendapat dari pertemuan pertama hingga pertemuan ketiga terdapat peningkatan dalam kriteria baik. Serta kualitas berpendapat dari pertemuan satu sampai pada pertemuan ketiga terdapat penurunan dalam kategori kurang baik.

\section{KETUNTASAN HASIL BELAJAR}

Data ketuntasan hasil belajar diperoleh guru dengan menggunakan cara yaitu membuat soal posttest. Hasil penilaian dari posttest digunakan oleh peneliti untuk mengetahui ketuntasan hasil belajar setelah diterapkannya model pembelajaran kooperatif tipe think pair share (TPS) pada materi asam basa. Soal posttest dikerjakan setelah menerima proses pembelajaran. Hasil yang didapatkan digunakan untuk mengetahui kemempuan akhir setelah dilakukannya penerapan pembelajaran. Posttest yang diberikan adalah soal pilihan ganda dengan total 15 butir soal. Berikut merupakan hasil posttest yang telah diperoleh. Tabel 6 .

Tabel 6 Nilai Posttest Peserta Didik

\begin{tabular}{llccc}
\hline No & Nama & KKM & $\begin{array}{l}\text { Nilai } \\
\text { Posttest }\end{array}$ & Keterangan \\
\hline 1 & AD & 77 & 93 & $\mathrm{~T}$ \\
2 & MI & 77 & 87 & $\mathrm{~T}$ \\
3 & MLA & 77 & 87 & $\mathrm{~T}$ \\
4 & AWN & 77 & 87 & $\mathrm{~T}$ \\
5 & RRP & 77 & 87 & $\mathrm{~T}$ \\
6 & DRA & 77 & 80 & $\mathrm{~T}$ \\
7 & AS & 77 & 100 & $\mathrm{~T}$ \\
8 & AAS & 77 & 87 & $\mathrm{~T}$ \\
9 & AEWR & 77 & 87 & $\mathrm{~T}$ \\
10 & FIA & 77 & 87 & $\mathrm{~T}$ \\
11 & MPD & 77 & 80 & $\mathrm{~T}$ \\
12 & RWP & 77 & 87 & $\mathrm{~T}$ \\
13 & MIRD & 77 & 87 & $\mathrm{~T}$ \\
14 & RP & 77 & 93 & $\mathrm{~T}$ \\
15 & DIL & 77 & 80 & $\mathrm{~T}$ \\
16 & MRA & 77 & 93 & $\mathrm{~T}$ \\
17 & KAA & 77 & 80 & $\mathrm{~T}$ \\
18 & MFA & 77 & 80 & $\mathrm{~T}$ \\
19 & PAD & 77 & 80 & $\mathrm{~T}$ \\
20 & ASZ & 77 & 87 & $\mathrm{~T}$ \\
21 & NPL & 77 & 93 & $\mathrm{~T}$ \\
22 & STW & 77 & 80 & $\mathrm{~T}$ \\
23 & SAD & 77 & 87 & $\mathrm{~T}$ \\
24 & SAZA & 77 & 87 & $\mathrm{~T}$ \\
25 & DTG & 77 & 87 & $\mathrm{~T}$ \\
26 & RAG & 77 & 87 & $\mathrm{~T}$ \\
27 & AA & 77 & 87 & $\mathrm{~T}$ \\
28 & FA & 77 & 87 & $\mathrm{~T}$ \\
29 & KRA & 77 & 80 & $\mathrm{~T}$ \\
30 & AM & 77 & 87 & $\mathrm{~T}$ \\
31 & RAF & 77 & 87 & $\mathrm{~T}$ \\
32 & SAP & 77 & 80 & $\mathrm{~T}$ \\
\hline & & & & \\
\hline
\end{tabular}


Tabel 6 menunjukkan data nilai hasil posttest diketahui bahwa 32 peserta didik mendapat keterangan tuntas semua. Hasil belajar dikatakan tuntas apabila mendapat nilai lebih dari 77. Ketuntasan klasikal kelas juga memperoleh nilai lebih dari 77 yaitu sebesar 86,18. Oleh karena itu penelitian ini dapat menuntaskan hasil belajar peserta didik pada materi asam basa.

\section{RESPON PESERTA DIDIK}

Perolehan angket respon dilakukan pada akhir pertemuan dan mendapatkan hasil yang positif karena didapatkan persentase $\geq 61 \%$. Berikut pemaparan hasil angket respon peserta didik:

Tabel 7. Hasil Respon Peserta Didik

\begin{tabular}{ccc}
\hline Pernyataan & $\begin{array}{c}\text { Persentase } \\
(\boldsymbol{\%})\end{array}$ & Kriteria \\
\hline 1 & 96,88 & Sangat baik \\
2 & 100 & Sangat baik \\
3 & 93,75 & Sangat baik \\
4 & 90,62 & Sangat baik \\
5 & 93,75 & Sangat baik \\
6 & 96,88 & Sangat baik \\
Rata-rata & 95,31 & Sangat baik \\
\hline
\end{tabular}

Berdasarkan Tabel 7 kesimpulan penerapan model pembelajaran kooperatif menggunakan tipe model TPS khususnya dalam materi kimia asam basa sebagai sarana untuk melatihkan keterampilan dalam berkomunikasi mendapat respon positif dari peserta didik. Persentasi ratarata dari seluruh pernyataan yaitu $95,31 \%$ dengan kriteria sangat baik. Respon positif tersebut menunjukkan bahwa guru telah berhasil menerapkan model pembelajaran kooperatif tipe TPS dan peserta didik telah dilatihkan keterampilan komunikasi.

\section{KESIMPULAN}

1. Keterlaksanaan pembelajaran dengan menerapkan model pembelajaran kooperatif tipe TPS pada pertemuan pertama sampai dengan ketiga secara berturut-turut setiap pertemuan mendapat penilaian sebesar 3,6; 3,75; dan 4 dengan kategori sangat baik.

2. Aktivitas peserta didik yang relevan pada setiap pertemuan tergolong baik, dengan persentase aktivitas yang relevan rata-rata setiap pertemuan sebesar $98,12 \%, 99,17 \%$, dan 99,3\%, hasil tersebut membuktikan bahwa peserta didik telah melaksanakan berbagai aktivitas yang relevan sesuai dengan model pembelajaran yang diterapkan yakni model pebelajaran kooperatif tipe TPS untuk melatihkan keterampilan komunikasi pada peserta didik dengan baik.

3. Keterampilan komunikasi yang berupa kuantitas bertanya secara berturutmendapatkan persentase sebesar $28,1 \%, 50 \%$, dan $56,2 \%$ dengan kriteria cukup baik, secara berturut-turut mencapai persentase sebesar $43,7 \%, 62,5 \%$, dan $65,6 \%$ dengan kriteria cukup baik. Keterampilan komunikasi yang berupa kualitas berpendapat, pada setiap pertemuan yang mendapat kriterian kurang baik berturut-turut mendapat presentase sebesar 56,25\%; 37,5\%; dan 34,37\% anak. kriteria cukup baik mendapat presentase sebanyak $0,6 \%, 0,6 \%$, dan $0,6 \%$ anak. Kriteria baik sebanyak $37,5 \%$; $56,25 \%$; dan $59,37 \%$ anak. Keterampilan komunikasi yang berupa kualitas bertanya peserta didik, pada setiap pertemuan yang mendapat kriterian kurang baik berturut-turut sebesar $65,52 \%, 50 \%$, dan $40,6 \%$ anak. Kriteria cukup baik medapat presentase sebanyak 34,37\%; 43,75\%, dan $53,12 \%$ anak. Kriteria baik sebanyak 0\%, $6,25 \%$, dan $6,25 \%$. Peningkatan jumlah peserta didik dengan kriteria cukup baik dari segi kualitas hal ini dapat menunjukkan bahwa keterampilan komunikasi peserta didik telah terlatih dengan model pembelajaran kooperatif tipe Think Pair Share (TPS).

4. Ketuntasan hasil belajar yang diperoleh peserta didik dalam penerapan model pembelajaran kooperatif tipe TPS memperoleh ketuntasan kalsikal sebesar $100 \%$ dengan skor-rata-rata postetst 86,15. 
5. Respon peserta didik terhadap penerapan model pembelajaran kooperatif tipe TPS yang dilakukan memperoleh hasil yang positif yang dibuktikan dengan besar persentase rata-rata yaitu sebesar $95,31 \%$ pada kriteria sangat memuaskan.

\section{SARAN}

1. Ketika proses pembelajaran berlangsung guru harus meminimalisasi adanya aktivitas tidak relevan yang dilakukan oleh peserta didik sehingga semua murid dapat lebih fokus selama pembelajaran berlangsung dan memperoleh hasil yang lebih maksimal guna meningkatkan keterampilan maupun hasil belajar.

2. Rata-rata kualitas bertanya peserta didik hanya terbatas pada kriteria Taksonomi Bloom tingkat $\mathrm{C} 1$ sampai dengan Taksonomi Bloom tingkat C3. Sehingga diharapkan kepada guru maupun peneliti selanjutnya untuk lebih meningkatkan kualitas bertanya mulai dari tingkat $\mathrm{C} 1$ sampai dengan tingkat $\mathrm{C} 6$.

3. Perlu adanya manajemen waktu dalam melakukan pembelajaran dan motivasi yang lebih baik dari guru maupun peneliti selanjutnya.

\section{DAFTAR PUSTAKA}

1. Permendikbud. 2016. Peraturan Menteri Pendidikan Dan Kebudayaan Nomor 69 Tahun 2013 Tentang Kerangka Dasar Dan Struktur Kurikulum Sekolah Menengah Atas/Madrasah Aliyah dan sederajat. Jakarta: Menteri Pendidikan dan Kebudayaan.

2. Wagner, T. 2010. The Gobal Achievement Gap Cambridge. Amerika: Harvard University.

3. Santrock, J.W. 2011. Psikologi Pendidikan. Jakarta: Prenada Media Group.

4. Sertel, A. 2015. The Effect of Cooperative Learning on Students' The Achievement and Views on the Scienc Metode. International Electronic Journal of Elementary Education. Vol 2, No 5.
5. Gillies, R.M. 2016. Cooperative Learning: Review of Research and Practice. Australian Journal of Teacher Education. Vol 41, No 3.

6. Demir, S. \& Celiker, D. 2016. Evaluation of the Uses of Acids and Bases in Daily Life. Journal of Studies Education. Vol. 6, No. 1.

7. Effendy, O.U. 2000. Dinamika dalam Komunikasi. Bandung: PT. Remaja Rosdakarya.

8. Maryati. 2010. Hubungan Antara Keterampilan Komunikasi Dengan Aktivitas Belajar Siswa. E-jorunal UNP. Vol. 1, No. 3.

9. Sari. N.K dan Muchlis. 2014. Implementasi Model Pembelajaran Kooperatif pada Tipe Tps Dengan Pendekatan Konstekual Untuk Melatihkan Sikap Jujur Pada Materi Kesetimbangan Kimia Di Sma Negeri 1 Ponorogo. Unesa Journal of Chemical Education. Vol. 3, No. 1.

10. Slavin, R..E. 2006. Educational Psychology Theory and Practice eighth edition. America: Jhons Honskin University.

11. Raba, A.A, Hogwe, R. dan Selli, M. 2017. The Influence of Think-Pair-Share (TPS) on Improving Communication Skills Classrooms. Creative Education Journal. Vol. 8, No. 3 .

12. Azlina, N.A.N. 2010. CETLs : Activities Among Student and Teachers Through the Use of Think-Pair-Share. IJCSI International Journal of Computer Science. Vol.7, No 4.

13. Nur, M. 2011. Model Pembelajaran Kooperatif tipe Think Pair Share. Edisi kedua. Surabaya: Pusat Sains dan Matematika Sekolah. Universitas Negeri Surabaya.

14. Arends, R.I. 2012. Learning to Teach. Penerjemah Helly Prajitno. Yogyakarta : Pustaka Belajar.

15. Gillies, R. 2014. Cooperative Learning: Developments Research. International Journal of Educational Psychology. Vol 3, No 2.

16. Nursalim, M, Satiningsih, Retno $T$, Nurhayati, dan Budiati, M. 2007. Ilmu Psikologi Pendidikan. Sutabaya: Universitas Negeri Surabaya Press. 
17. Riduwan. 2012. Skala Pengukuran VariabelVariabel Penelitian. Bandung: Alfabeta Press.

18. Sudjana. 2002. Penilaian Proses Hasil Belajar Mengajar. Bandung : PT. Remaja Rosda.
19. Changara, H. 2016. Pengantar Ilmu Komunikasi. Edisi kedua. Jakarta: PT. Raja Grafindo Persada.

20. Anderson, L.W dan David, R.K. 2001. A Revision of Bloom's Toxonomy of Educational Objectives. New York: Allyn dan Bacon Facione, P.A. 